\title{
THE SYSTEMS APPROACH TO INNOVATION STUDIES
}

\author{
Dr Karen Manley \\ School of Construction Management and Property, Queensland University of Technology
}

\begin{abstract}
The academic literature, and business practice, reveals a shift in the way analysts understand innovation processes. This shift is not revealed as a cohesive trend, rather it comprises contributions from a wide range of academic disciplines and empirical evidence. Building on Edquist (1997) this paper ties together the diverse new ideas which stress a systems approach to successful innovation. The paper presents an up-to-date overview of this fast moving field, with a view to assisting public policy makers and business managers in designing more effective innovation processes.
\end{abstract}

Keywords: innovation systems, business networking, literature review

\section{INTRODUCTION*}

*The author is grateful to the Queensland Department of Main Roads, the Australian Research Council and Queensland University of Technology for supporting research associated with this paper.

Defined simply, innovation can be regarded as new creations of economic significance. Innovation is widely regarded as critical to economic growth processes. The academic literature contains considerable evidence of the value of innovation in driving growth. In commenting on such evidence, Edquist (1997: 1) notes that: '[i]t is almost universally accepted that technological change and other kinds of innovations are the most important sources of productivity growth and increased material welfare...' (eg. OECD 2000). Yet despite the value of innovation, it is only over the past decade or so that considerable progress has been made in understanding the key features of successful innovation. Such progress has hinged on taking a systems perspective. This new perspective has the potential to improve innovation outcomes for firms, industries, regions and nations, through better informed public-policy and business initiatives.

This shift to systems thinking is not revealed as a cohesive trend in the academic literature, nor in business practice, rather it comprises contributions from a wide range of academic disciplines and empirical evidence. It is the aim of this paper to bring together the diverse ideas on innovation systems, building on the substantial contribution of Edquist (1997). This paper presents an up-to-date overview of this fast moving field, with a view to it assisting public policy makers and business managers in designing more effective innovation systems.

\section{FROM LINEAR INNOVATION PROCESSES TO INNOVATION SYSTEMS}

During the 1950s, 1960s and 1970s, most innovation analysts viewed innovation processes as predominantly linear. The first linear model developed to explain innovation was the science-push approach where innovation was seen to begin with 'scientific discovery, passing through invention, engineering and manufacturing activities and ending with the marketing of a new product or process' (Dodgson 2000: 17). The second linear model developed, the demand-pull model, portrayed innovation as being stimulated by demand. The figure below summarises the two models.

Figure 1: Linear Models of the Innovation Process

\section{Science-Push Model}

Basic Science $\rightarrow$ R\&D $\rightarrow$ Production/Construction $\rightarrow$ Marketing

Demand-Pull Model

Demand $\rightarrow \mathrm{R \& D} \rightarrow$ Production/Construction $\rightarrow$ Sales


Note that neither model incorporates any feed-back mechanisms, failing to account for multi-directional information flows - such as input into R\&D by manufacturers or marketers.

During the 1980s, more interactive models were developed so that by the 1990s, systems approaches had appeared, representing more complex views of innovation processes. Such 'interactive' models are strongly supported by empirical evidence and are also intuitively appealing. A general form of this model may be represented as follows.

Figure 2: Interactive Model of the Innovation Process

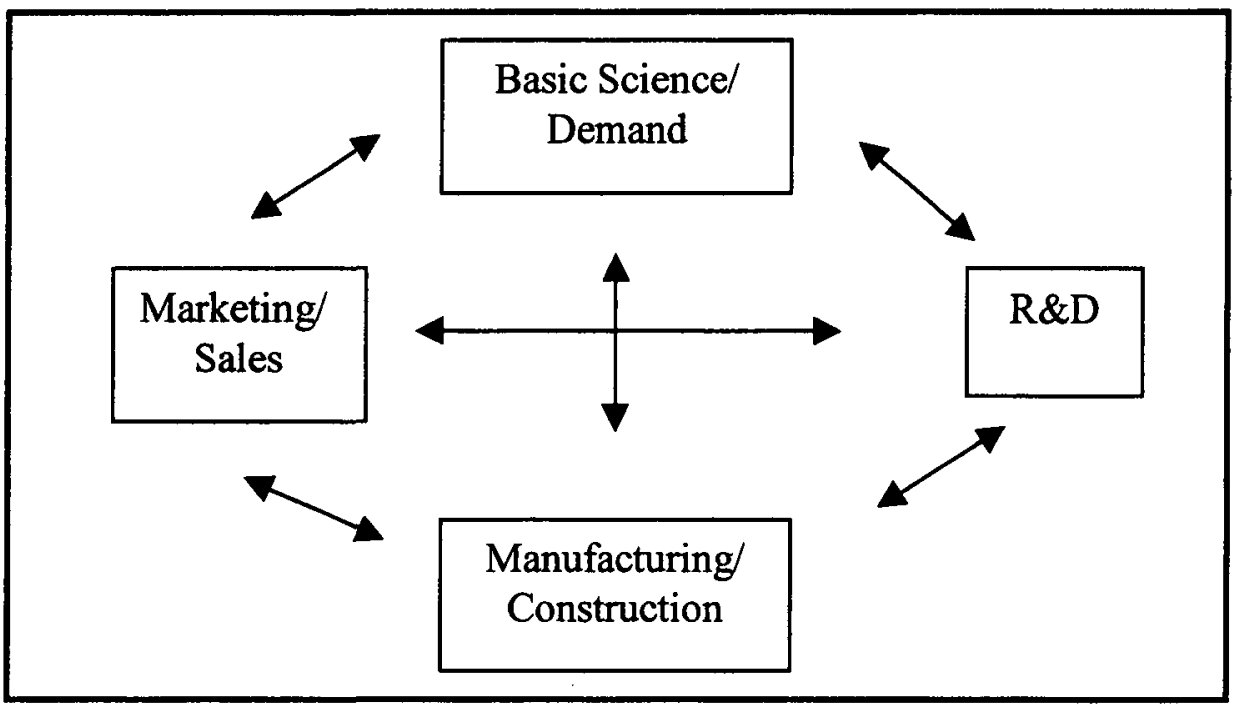

This model highlights the existence of feedback loops between all stages in the innovation process. Innovation is now understood as the result of interaction between various economic and social processes. These processes are rapidly increasing in complexity, through forces such as the IT revolution and globalisation. To manage this complexity in the pursuit of innovation and growth, individual organisations need the capabilities of others. Hence, the dominant unit of analysis in innovation studies has shifted from individual organisations, to groups of organisations in innovation systems, their interaction and potential for learning. Indeed, 'learning has become the central core of the new canonical thinking about the source of wealth of nations' (de la Mothe and Paquet 1998: 328).

This new 'systems' way of thinking has been gaining momentum from the 1970 s to the present day, during which time a number of highly influential studies have emerged, including Dosi et al (1998), Porter (1990), Lundvall (1992), Nelson (1993), Carlsson (1995) and OECD (1999b; 1999c) These studies all point to innovation processes driven by knowledge, relationships and learning, in the context of collaborations with external parties. These collaborations may be informal or formal; they often involve clients, customers, research organisation, regulators, finance providers and related organisations. A wide range of system configurations are replacing solo innovation efforts as firms adjust to their more complex surroundings.

Interactive innovation processes lie at the heart of success in the new economic circumstances. As the BIE (1991:7) notes:

'For some time, studies of the innovation process have stressed the importance of networks to successful innovation, over-turning the traditional model which characterises innovation as a linear sequence running from basic research, through product development, to production and marketing. Innovation is now seen as an interactive process requiring intense traffic in facts, ideas and reputational information within and beyond the firm'.

The interactive view of innovation shown in Figure 2 is the basis for a number of useful conceptual elaborations of the innovation process, all of which emphasise the increasing complexity of successful innovation and the importance of external knowledge sources. These approaches include: networks (Freeman 1991); value-chains (Walters and Lancaster 2000), clusters (Porter 1990; OECD 1999c), development blocks (Dahmen 1988), complexes (Glatz and van Tulder 1989; Marceau 1995), innovation milieux (Camagni 1991; Ratti et al 1997), complex products and systems (Research Policy, 29 2000); competence blocs (Eliasson 1997); and innovation systems (Edquist 1997). Many of the ideas contained in these approaches fall broadly into an innovation systems 
perspective, which is the subject of this paper as it currently receives the most attention from policy-makers and business people. Readers interested in a broader review of associated literature are referred to Manley (2001).

\section{INNOVATION SYSTEMS}

Although the innovation system approach emerged only a decade or so ago, Edquist and McKelvey (2000: xi) note it has:

... diffused surprisingly fast in the academic world as well as in the realms of public innovation policy making and firm innovation strategy formulation. The OECD has been particularly influential in using and further developing empirical analyses and research using this approach. 'Systems of innovation' is at the centre of modem thinking about innovation and the relations of innovation to economic growth, competitiveness and employment.

The systems perspective recognises that innovation is a collective undertaking where innovating organisations interact with others in particular institutional settings. Innovations are developed in systems where organisations and institutional rules are key elements. System approaches to innovation focus on the nature and impact of the collective character of innovation. System features will have a 'decisive impact on the extent to which firms can make innovation decisions, and on the modes of innovation which are undertaken' (Edquist 1999: 7-8).

The innovation system approach is 'holistic and interdisciplinary' and has the potential to encompass all the determinants of innovation. It differs from earlier analytical approaches in assuming that innovation relies primarily on interactions between institutions and people (Landry and Amara 1998: 261).

All the features of innovation systems stem from the collective nature of successful innovation efforts. For any organisation, success relies on relationships with external parties. This view is supported by numerous empirical studies, an example of which is a rigorous examination of an innovation system by Landry and Amara (1998: 274). Their case-study work indicates that 'innovative firms develop more interactions with outside sources of ideas, information and technology than non-innovative firms do'. In may respects, an innovation system is a social system in which innovations emerge partly as a result of social interaction between economic actors from different organisations (Cooke 1998: 11).

The OECD has played a major role in the mobilisation of this approach to understanding economic growth. According to the OECD, innovation is the result of a complex set of linkages between actors creating, applying and distributing various kinds of knowledge. Innovation performance depends critically on 'the way these actors relate to each other as elements of a collective system of knowledge creation and use ... ' (1997a: 9).

The following sections highlight four key drivers of innovation in contemporary innovation systems knowledge flows, institutions, economic competence and interactive learning. These are the main innovation inputs discussed in the literature.

\section{Knowledge Flows}

The current popularity of the innovation system approach reflects the increasing knowledge intensity of economic activity. A key variable of interest is the 'knowledge distribution power' of a particular system, which involves the system's ability to facilitate effective knowledge flows. Analysis of a particular system will involve tracking the linkages between industry, government and academia in the development of technological and organisational innovations. A key policy aim is to identify the main channels of knowledge flow, to evaluate bottlenecks and to suggest approaches to improve the effectiveness of knowledge diffusion (OECD 1997a: 11).

The OECD has developed a model to guide empirical studies of knowledge flows in innovation systems, as shown in Table 1. 
Table 1: Assessing Innovation Systems

\author{
Four Basic Flows of Knowledge: \\ Joint Activities between Firms \\ technical collaboration \\ informal interactions (tacit knowledge transfer) \\ 2. Joint Activities between Firms and Public-Sector R\&D \\ Providers \\ technical collaboration \\ informal interactions (tacit knowledge transfer) \\ Innovation Diffusion \\ adoption of new processes, equipment \\ and machinery developed elsewhere \\ Personnel Mobility \\ flows of tacit knowledge
}

Five Key Research Methods:

1. firm surveys

2. literature-based alliance counting

3. value of research contracts

4. co-patents and co-publications

5. citation analysis

Source: OECD 1997a

In this model, four key types of knowledge flows are highlighted - joint firm collaboration, joint privatesector/public-sector collaboration, innovation diffusion and personnel mobility.

Joint activities between firms often take the form of collaboration between producers to pool technical resources, gain economies of scale and achieve synergies from complementary technical and human assets. User-producer interaction is also important in stimulating innovation. In both cases - producer/producer and user/producer interaction, formal and informal relations are important.

Joint activity between firms and public-sector R\&D providers typically takes the form of contracts for R\&D undertaken by the public-sector. The value of these linkages is determined by the quality of the research infrastructure and its accessibility to firms. Private/public-sector interaction is particularly valuable within innovation systems, as the public-sector is often a key performer of $R \& D$ and resultant knowledge needs to be transferred to users in order to promote innovation and growth.

Innovation diffusion - the adoption of advanced methods and technologies by new users - this is the most traditional form of knowledge flow in innovation systems (OECD 1997a). The innovation performance of a particular system depends critically on the rate of such adoption and investment in appropriate adaption to ensure successful implementation.

The movement of personnel and their knowledge capital is considered another key flow in innovation systems (OECD 1997a). Personnel mobility reflects the movement of tacit knowledge - knowledge which cannot be written down, which is often critical in the successful integration of innovations produced by external parties.

As noted in Table 1, there are five basic methods available for gathering data on knowledge flows:

1. Firm surveys which involve the use of questionnaires and personal interviews to elicit information on collaborative behaviour and the sources of knowledge for innovation, particularly with regard to tacit knowledge flows.

2. Literature-based alliance counting which gives a rough idea of the nature and extent of the different types of alliances within which knowledge is exchanged. It involves reviews of newspapers, journal articles, specialised books and journals, together with corporate annual reports and industry directories.

3. Analysis of research contracts indicates the extent to which the private-sector is linked to public-sector R\&D capabilities. Information about the value of such contracts can be obtained from government funding sources, universities, private-sector research bodies and/or private-sector users.

4. The number of co-patents and co-publications, indicating inter-firm collaboration and private-public sector collaboration, can be ascertained from patent records and publication indices. 
5. Users of R\&D cite patents and publications in their literature on new developments. These citations can be counted and analysed to reveal collaboration patterns, particularly between the private and public sectors.

This OECD approach focuses on the role of knowledge in innovation systems. Statistics Canada (Anderson and Manseau 1999: 3) also focuses on the role of knowledge, and its movement from the site of generation to the site of use, which requires:

- a means of transmitting knowledge between sites;

- the capacity of knowledge generators to transmit knowledge; and

- the capacity of knowledge users to search for and absorb knowledge.

From an individual firm's perspective, knowledge sites include those internal to the firm and those found in the external environment, for example (Landry and Amara 1998: 265):

Market sources

- clients

- competitors

- suppliers

- consultants

Education and R\&D providers

- universities

- public and private R\&D organisations

Local, state and national framework providers

- regulators

- finance providers

- trainers

- unions

- professional associations

Generally available information

- fairs/exhibitions

- conferences/workshops/seminars

- joumals

- patent disclosure

Institutions play an important role in determining the efficacy of knowledge flows between sources such as those described above.

\section{Institutions}

Institutions are the 'rules of the game' which govern how knowledge moves between system participants and the way in which subsequent learning and innovation takes place. Nooteboom (2000:916) suggests that firm-level innovation outcomes are, to a large extent, dependent on the institutional context.

The following key institutions affect the performance of innovation systems (based on Amable and Petit 1999: 12):

- the finance system;

- the taxation system;

- the intellectual property rights system;

- the training system;

- the education system;

- the industrial relations system;

- labour markets;

- the internal structure of corporate firms and government bodies;

- conceptions of faimess and justice held by capital and labour;

- the structure of the state and its policies; and

- idiosyncratic customs, traditions, norms, moral principles, rules, laws, standards and routines. 
The innovation performance of organisations is strongly influenced by these institutions. For example, if the education and training systems are under-resourced by government, firms may find it difficult to access suitably skilled employees to support their innovation efforts. Another example is the Australian federal government cutting back of the $150 \%$ R\&D Tax Concession in 1996 which had a significant impact on R\&D expenditure in Australia (see Marceau and Manley 1999). On a more positive note, Australian culture tends to support early adoption of new innovations, which can help tie Australia into global innovation systems.

\section{Interactive learning}

Another key feature of innovation systems is interactive learning. The term interactive learning implies a - reliance on multiple sources of tacit knowledge in the leaming process. In turn, learning has been shown to be a key input in the innovation process (eg. Dodgson 1996). Dosi (1988: 222-223) observes that there are five problematic features of innovation processes that require interactive learning in order to promote positive outcomes, these are:

Uncertainty: including the lack of full information about the occurrence of known events, the existence of techno-economic problems whose solution procedures are unknown, and the inability to predict precisely the consequences of one's actions. The involvement of multiple players in interactive learning increases the stock of knowledge and the breadth of experience that can be drawn on to reduce uncertainty in the innovation process.

Scientific Knowledge: the increasing reliance of major new technological opportunities on advances in scientific knowledge highlights the importance of linkages between $R \& D$ users and major $R \& D$ organisations in interactive learning.

Complexity: the increasing complexity of R\&D activity means that multiple players are needed in order to access multiple knowledge sources, rather than just relying on the skills of individual innovators.

Experimentation: the increasing role of experimentation in the form of learning-by-doing and learning-by-using requires access to appropriate partners to maximise the value of experimentation.

Cumulativeness: the cumulative character of innovative activity means that past decisions shape future opportunities. Hence, it is important to keep options open by maintaining a broad array of innovation interests through multiple relationships, through activities such as: user-producer interaction, formal R\&D agreements, professional association functions, consultations with regulators/training organisations/fiance providers, production agreements, licencing, joint ventures, sub-contracting and conference/workshop/forum attendance. In summarising the importance of interactive learning, Lundvall (1999: 3) notes that 'the last decade has witnessed a change in the mode of competition that implies that interactive learning, and forgetting, has become the most important process for determining the position of individuals, firms, regions and countries in competition'.

\section{Economic Competence}

The final feature of innovation systems reviewed here is the economic competence of a system's participants. The outcomes of interactive innovation process are 'a function of the level and content of economic competence on the part of various agents within the system' (Carlsson and Stankiewicz 1991: 113). This quality, or economic competence, is the microfoundation upon which the success of the innovation system will rest. Economic competence involves the ability to initiate and exploit new business opportunities. It is a 'scarce and unequally distributed resource ... not all economic agents ... are equally adept at generating new ideas or absorbing new ideas from outside' (Carlsson and Stankiewicz 1991: 94). Carlsson et al. (1999: 5) identify four crucial types of firm-level competence in innovation systems:

1. Selective/strategic ability: the ability to: make innovative choices between markets, products, technologies and organisation structures; engage in entrepreneurial activity; select key personnel; and acquire other key resources, including new competencies. An important part of strategic capability is the notion of receiver competence or absorptive capacity, which involves the ability to scan and monitor relevant technological and economic information; identify technical and market opportunities; and acquire knowledge, information and skills needed to exploit opportunities.

2. Organisational/integrative/coordinating ability: the ability to organise and coordinate resources and economic activities within the organisation so that overall objectives are met. This includes the ability to generate and improve technologies through new combinations of existing knowledge and skills. This should be the main function of middle management in an organisation.

3. Technical/functional ability: the efficient execution of various functions within the firm to implement technologies and utilise them effectively in chosen markets. 
4. Learning/adaptive ability: the ability to learn from success as well as failure, to identify and correct mistakes, and to diffuse technology throughout the organisation. This ability is essential for long-term survival. A firm that is both effective and efficient at a point in time eventually becomes neither unless it can adapt to changing circumstances (especially changing technology).

Later research by Nooteboom et al. (2000: 120) suggests that a fifth relational ability is required.

5. Relational ability: the ability to focus on core competencies and utilise complementary resources from other firms. This ability has increased in importance in recent years due to the pressures of globalisation, the increasing complexity of input and output markets and the increasing speed of technical change.

The presence of these five abilities in the organisations which make up an innovation system will greatly assist the system's performance, particularly by improving the value of interactive learning opportunities.

\section{CONCLUSIONS}

This paper has touched on four key drivers of innovation in innovation systems - knowledge flows, institutions, interactive learning and economic competence. These drivers are the main ones to emerge from analysis of a wide range of contributions to the academic literature. Compared to earlier linear approaches to understanding innovation processes, systems thinking has contributed a great deal to our understanding of effective innovation processes.

Although the literature acknowledges that an ideal system is not possible to specify (Edquist 1997: 20), the following guidelines concerning the nature of a well-performing innovation system can be put forward:

Organisations: An innovation system is more likely to be effective if it includes a diverse range of organisations with different types, and high levels of, economic competence. The system is likely to operate more effectively if it includes firm and non-firm organisations, demanding customers, and new industry players.

Institutions: Innovation system performance is critically affected by institutional arrangements. Critical institutions, such as those relating to training, education, finance and intellectual property need to incorporate arrangements that are supportive of innovation.

Linkages with external parties: Maximum advantage will be gained if external linkages are dense, multistranded, long-term, knowledge-intensive, vertical and horizontal, market and non-market oriented, and inclusive of innovation, production and distribution relationships. Such factors support the development of effective dynamics within innovation systems.

Outcomes: Innovation system outcomes will be maximised if individual participants perceive benefits beyond what they could achieve in isolation. The system is then more likely to be stable and productive.

In the rapidly changing environment of the $21^{\text {st }}$ century, the ability of businesses and governments to generate growth and jobs will rest critically on their innovation performance. The systems framework represents a new and increasingly popular approach to understanding and improving that performance.

\section{REFERENCES}

Anderson, F. and Manseau, A. (1999) A Systemic Approach to Generation/Transmission/Use of Innovation in Construction Activities. Paper presented at the Third International Conference on Technology Policy and Innovation: Global Knowledge Partnership-Creating Value for the $21^{\text {st }}$ Century, Austin, Texas, 30 August - 2 September 1999.

Amable, B. and Petit, P. (1999) On Institutions, Innovation and Growth. Provisional draft of paper presented at the Danish Research Unit for Industrial Dynamics Summer Conference on National Innovation Systems, Industrial Dynamics and Innovation Policy, Rebild, 9-12 June 1999.

Archibugi, D., Howells, J. and Michie, J. (1999) 'Innovation Systems and Policy in a Global Economy'. In D. Archibugi, J. Howells and J. Michie (eds) Innovation Policy in a Global Economy, UK: University of Cambridge, 1-16.

Braczyk, H-J, Cooke, P. and Heidenreich, M. (1998) Regional Innovation Systems: The Role of Governances in a Globalised World, London: UCL Press.

Breschi, S. and Malerba, F. (2000) 'Sectoral Innovation Systems: Technological Regimes, Schumpeterian Dynamics, and Spatial Boundaries'. In C. Edquist (ed.) Systems of Innovation: Technologies, Institutions and Organisations, Chapter 6, London and Washington: Pinter, 130-156.

BIE (Bureau of Industry Economics) (1991) 'Networks: a third form of organisation'. Bulletin on Industry Economics, 10: 5-9. 
BIE (Bureau of Industry Economics) (1995) Beyond the Firm. An assessment of business linkages and networks in Australia. Canberra: AGPS.

Camagni, R. (ed.) (1991) Innovation Networks: Spatial Perspective's. Belhaven: London.

Carlsson, B. and Stankiewicz. (1991) 'On the Nature, Function and Composition of Technological Systems'. Journal of Evolutionary Economics, 1: 93-118.

Carlsson, B., Jacobsson, S., Jolmen, M. and Rickne, A. (1999) Innovation Systems: Analytical and Methodological Issues. Danish Research Unit for Industrial Dynamics Working Paper.

Cooke, P., Uranga, M.G., and Extebarria, G. (1997) 'Regional Innovation systems: Institutional and Organisational Dimensions'. Research Policy, 26: 475-491.

Dahmen, E. (!988) ‘Development Blocks in Industrial Economics'. Scandinavian Economic History Review and Economic History, XXXVI(1): 3-14.

de la Mothe, J. and Paquet, G. (1998) 'Local and Regional Systems of Innovation as Learning SocioEconomics'. In J. de la Mothe and G. Paquet (eds) Local and Regional Systems of innovation, Boston, Dordrecht and London: Kluwer Academic Publishers, 1-16.

de la Mothe, J. and Paquet, G. (1998b) 'Some Lessons and Challenges for Model Builders, Data Gatherers and Other Tribes'. In J. de la Mothe and G. Paquet (eds) Local and Regional Systems of innovation, Boston, Dordrecht and London: Kluwer Academic Publishers, 327-334.

DeBresson, C. and Amesse, F. (1991) 'Networks of Innovators: A Review and Introduction to the Issue'. Research Policy, 20: 363-379.

Dodgson, M. (1996) 'Technology and Innovation: Strategy, Learning and Trust'. In Sheehan, P., Grewal, B. and Kumnick, M. (eds) Dialogues on Australia's Future. Melbourne: Centre for Strategic Economic Studies, Victoria University.

Dodgson, M. (2000) Systemic Integration of the Innovation Process within the Firm. Contributed paper \#2 at the National Innovation Summit, Melbourne, 9-1 1 February 2000.

Dosi, G., Freeman, C., Nelson, R., Silverberg, G. and Soete, L. (eds) (1988) Technical Change and Economic Theory. London: Frances Pinter.

Easton, G. (1992) 'Industrial Networks: A Review'. In B. Axelsson and G. Easton (eds) Industrial Networks: A New View of Reality. London and New York: Routledge, 1-27.

Edquist, C. (1997) Systems of Innovation: Technologies, Institutions and Organisations. London: Pinter.

Edquist, C. (1999) Innovation Policy - A Systemic Approach. Incomplete draft of paper presented at the Danish Research Unit for Industrial Dynamics Summer Conference on National Innovation Systems, Industrial Dynamics and Innovation Policy, Rebild, 9-12 June 1999.

Edquist, C. and M. McKelvey. (2000) 'Introduction'. Systems of Innovation: Growth, Competitiveness and Employment, Volume 1. Cheltenham, UK: Edward Elgar Publishing Limited, xi-xxii

Eliasson, G. (1997) Competence Blocks and Industrial Policy in the Knowledge Based Economy. Stockholm: Department of Industrial Economics and Management, The Royal Institute of Technology.

Fagerberg, J. (1995) 'User-Producer Interaction, Learning and Comparative Advantage'. Cambridge Journal of Economics, 19: 243-256.

Freeman, C. (1987) Technology Policy and Economic Performance: Lessons from Japan. London: Pinter.

Freeman, C. (1991) 'Networks of Innovators: A Synthesis of Research Issues'. Research Policy, 20: 499-514.

Glatz, H. and van Tulder, R. (1989) Ways out of the International Restructuring Race? Project Proposal, Annex, B. University of Amsterdam, Amsterdam.

Howells, J. (1999) 'Regional Systems of Innovation?'. In D. Archibugi, J. Howells and J. Michie (eds) Innovation Policy in a Global Economy, UK: University of Cambridge, 67-93.

Howells, J. and Roberts, J. (2000) 'From Innovation Systems to Knowledge Systems'. Prometheus, $18(1)$ : 17 31.

Landry, R. and Amara, N. (1998) 'The Chaudiere-Appalaches System of Industrial Innovations'. In J. de la Mothe and G. Paquet (eds) Local and Regional Systems of innovation, Boston, Dordrecht and London: Kluwer Academic Publishers, 257-276.

Lundvall, B- A (1988) 'Innovation as an interactive process: from user-producer interaction to the national system of innovation. In Dosi, G., Freeman, C., Nelson, R., Silverberg, G. and Soete, L. (eds) Technical Change and Economic Theory. London: Pinter.

Lundvall, B-A. (1992) National Systems of Innovation. London: Pinter.

Lundvall, B-A. (1999) The Danish Innovation System. Discussion Paper on the Challenges and Opportunities for Innovation Policy. The Concluding DISKO Report. Copenhagen: Erhvervsfremme Styrelsen.

Malerba, F. (1999) Sectoral Systems of Innovation and Production. Paper presented at the Danish Research Unit for Industrial Dynamics Summer Conference on National Innovation Systems, Industrial Dynamics and Innovation Policy, Rebild, 9-12 June 1999. 
Manley, K. (2001) 'Innovation Systems - Developing an Integrated Framework for Investigating the Queensland Road Sector'. Queensland Department of Main Roads, Brisbane.

Marceau, J. (1995) 'A Networked Nation or a Complexes Issue? Reshaping Industry Analysis'. Journal of Industry Studies, 2(2): 19-33.

Marceau, J. and Manley, K. (1999) 'Innovation Checkpoint 1999 - Innovation in Australian Businesses'. Australian Business Foundation, Sydney.

Nelson, R. (Ed) (1993) National Innovation Systems. New York: Oxford University Press.

Nooteboom, B. (2000) 'Institutions and Forms of Co-ordination in Innovation Systems'. Organisation Studies, 21(5): 915-939.

Nooteboom, B., deJong, G., Vossen, R.W., Helper, S. and Sako, M. (2000) 'Network Interactions and Mutual Dependence: A Test in the Car Industry'. Industry and Innovation, 7(1): 117-144.

Normann, R. and Ramirez, R. (1993) 'From Value Chain to Value Constellation: Designing Interactive Strategy'. Harvard Business Review, 71(July-August): 65-78.

OECD (1996) The Knowledge-Based Economy. Paris: OECD

OECD (1997) National Innovation Systems: Paris: OECD.

OECD (1999a) The Knowledge-Based Economy: A Set of Facts and Figures. Paris: OECD

OECD (1999b) Managing National Innovation Systems. Paris: OECD.

OECD (1999c) Boosting Innovation: The Cluster Approach. Paris: OECD.

OECD (2000) A New Economy? The Changing Role of Innovation and Information Technology in Growth. Paris: OECD.

Patel, P. and Pavitt, K. (1994) 'National Innovation Systems: Why They Are Important, and How They Might Be Measured and Compared'. Economics of Innovation and New Technology, 3: 77-95.

Porter, M. (1990) The Competitive Advantage of Nations. New York: Free Press.

Porter, M. (1990) 'The Competitive Advantage of Nations'. Harvard Business Review, March-April: 73-93.

Porter, M. E. (1998) 'Clusters and the New Economics of Competition'. Harvard Business Review, NovemberDecember: 77-90.

Ratti, R., Bramanti, A. and Gordon, R. (1997) The Dynamics of Innovative Regions. England: Ashgate.

Rosenberg, N. (1982) Inside the Black Box. Cambridge: Cambridge University Press.

Sornn-Friese, H. (2000) 'Frontiers of Research in Industrial Dynamics and National Systems of Innovation'. Industry and Innovation, 7(1): 1-13.

Statistics Canada (1999) Innovation, Advanced Technologies and Practices in the Construction and Related Industries. Survey for Science and Technology Redesign Project.

Statistics Canada (1999) Survey of Innovation 1999. Survey by Science, Innovation and Electronic Information Division, Statistics Canada.

Von Hippel, E. (1988) The Sources of Innovation. New York: Oxford University Press.

Walters, D. and Lancaster, G. (2000) 'Implementing Value Strategy Through the Value Chain'. Management Decision, 38(3): 160-178. 